\title{
PELUANG DAN TANTANGAN BUDIDAYA IKAN DI DANAU MANINJAU PROVINSI SUMATERA BARAT
}

\author{
Adang Saputra \\ Pusat Riset Perikanan Budidaya \\ Jl. Ragunan 20, Pasar M inggu, Jakarta Selatan 12540 \\ E-mail: adang@ cria.indosat.net.id
}

\begin{abstract}
ABSTRAK
Implementasi pelaksanaan program pembangunan perikanan secara nasional telah tercermin dalam Rencana Strategis (Renstra) Kementerian Kelautan dan Perikanan dalam visinya yang menyatakan: Indonesia penghasil produk perikanan terbesar tahun 2015. Salah satu lokasi yang potensial untuk pengembangan kegiatan budidaya perikanan air tawar adalah Danau Maninjau. Kegiatan budidaya ikan di Danau Maninjau dengan keramba jaring apung (KJA) mulai berkembang pada tahun 1990. Tingkat pencemaran perairan Danau Maninjau sudah cukup kritis untuk air minum (kelas I dan II), tetapi untuk perikanan masih termasuk dalam ketegori tercemar ringan. Komoditas yang menjadi unggulan di Danau Maninjau adalah ikan mas dan ikan nila yang baru mulai berkembang. Peluang usaha budidaya ikan di Danau Maninjau masih terbuka luas, baik pada segmen budidaya, distribusi pakan, perbenihan, transportasi, maupun pemasaran hasil. Kendala adalah penyediaan benih unggul khususnya ikan mas masih harus didatangkan dari luar Kabupaten Agam Provinsi Sumetera Barat, untuk ikan nila sampai saat ini belum ada kendala.
\end{abstract}

KATAKUNCl: Danau Maninjau, budidaya ikan, pencemaran, keramba jaring apung

\section{PENDAHULUAN}

Sektor perikanan merupakan salah satu sektor yang strategis dalam percepatan pembangunan perikanan nasional. Namun demikian, implementasi percepatan pembangunan perikanan secara nasional harus memperhitungkan tantangan perubahan lingkungan ekosistem perairan yang terus bergerak dengan sangat dinamis.

Implementasi pelaksanaan program pembangunan perikanan secara nasional telah tercermin dalam Rencana
Strategis (Renstra) Kementerian Kelautan dan Perikanan dalam visinya yang menyatakan: Indonesia harus menjadi penghasil produk perikanan terbesar tahun 2015. Upaya yang harus dilakukan dalam mewujudkan visi tersebut adalah membangun ekonomi perikanan secara terpadu dengan mengoptimalkan pemanfaatan sumberdaya perairan baik tawar, pantai, maupun laut secara seimbang dan berkelanjutan (sustainable).

Salah satu lokasi yang potensial untuk pengembangan kegiatan budidaya perikanan air tawar adalah Danau Maninjau. Danau Maninjau merupakan danau alami termasuk kategori danau vulkanik yang terletak di Kabupaten Agam Provinsi Sumatera Barat (Gambar 1). Luas permukaan air Danau Maninjau 9.737,50 ha dengan volume air 10.226.003.624,2 $\mathrm{m}^{3}$, dan kedalaman maksimum $165 \mathrm{~m}$, serta keliling danau sekitar $75 \mathrm{~km}$. Mempunyai nilai ekonomi dari sektor perikanan sebesar Rp 43,3 milyar/tahun (LIPI, 2007).

Oleh karena itu, Danau Maninjau memiliki fungsi ekonomis penting bagi mayarakat dan Pemerintah Kabupaten Agam khususnya dari sektor perikanan budidaya. Kegiatan budidaya ikan dengan keramba jaring apung (KJA) merupakan salah satu aspek pengelolaan terpadu suatu ekosistem perairan, sebagai bagian yang tidak terpisahkan dalam pemanfaatan perairan danau sehingga tidak saling berbenturan. Dengan harapan ekosistem perairan Danau Maninjau tetap dijaga dan lestari.

\section{KONDISI PERAIRAN DANAU MANINJAU}

Danau Maninjau dibangun pada tahun 1983, dengan air keluar tidak melalui saluran pengeluaran alaminya (Sungai Batang Antokan) tetapi melalui intake PLTA dengan laju 13,39 m³/detik (LIPI, 2007). Dalam perkembangannya, selain pemanfaatan untuk pembangkit tenaga listrik juga sektor lain turut berkembang di antaranya kegiatan budidaya ikan dengan sistem KJA, yang berkembang mulai tahun 1990 (Gambar 2).

Pada akhir tahun 2008 sampai awal tahun 2009 fungsi perikanan budidaya mengalami kendala yang sangat berat, 


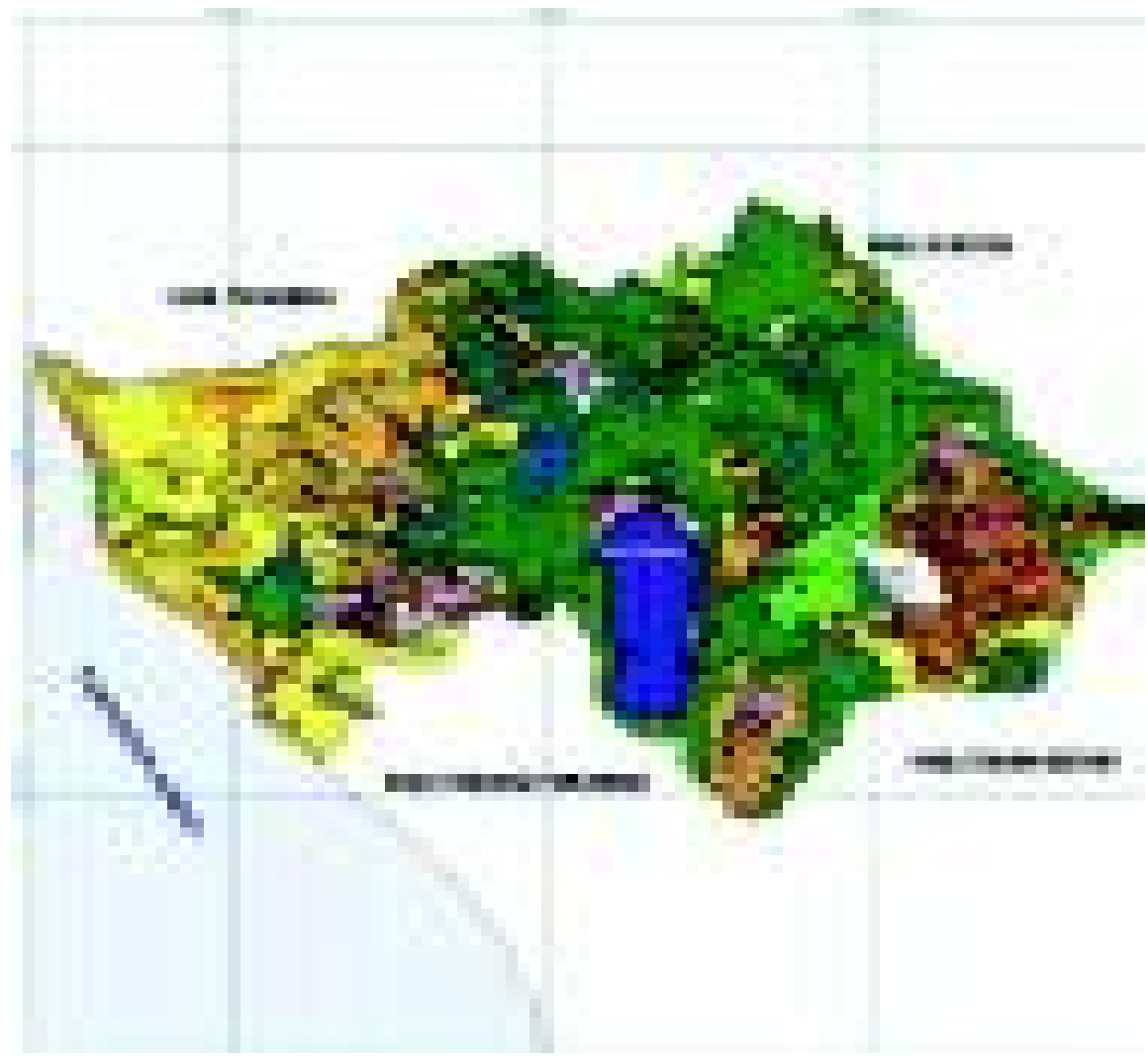

Sumber: Jusuf et al. (2005)

Gambar 1. Hasil klasifikasi penutup lahan Kabupaten Agam

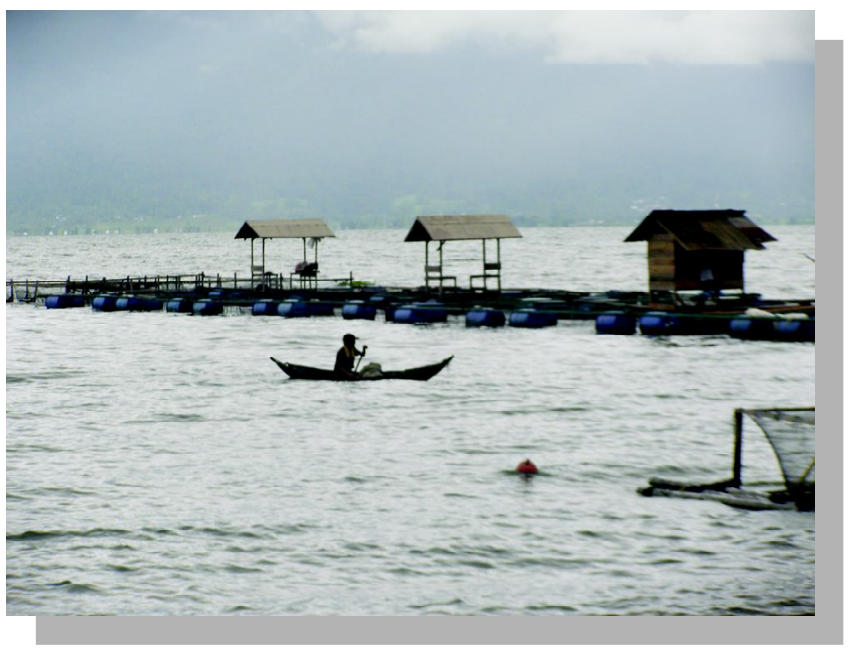

Gambar 2. Kegiatan budidaya ikan dalam KJA di Danau Maninjau

hal ini dikarenakan adanya dampak fenomenal "tubo belerang" atau natural upwelling di danau yang mengakibatkan kematian ikan yang tinggi sehingga para pembudidaya mengalami kerugian. Dampak dari fenomena natural upwelling ini adalah menurunnya kualitas air yang ditandai oleh bau yang menyengat, menimbulkan rasa gatal bila mengenai kulit, dan terjadinya blooming alga pengganggu terutama Microcystis aeruginosa (LIPI, 2007). Peristiwa ini merupakan musibah terbesar bagi perekonomian Kabupaten Agam dalam sepuluh tahun terakhir dengan tingkat kerugian mencapai sekitar Rp 140 milyar dan menguras modal para pembudidaya ikan ( \pm 1.092 orang).

Secara umum isu dan tantangan yang berhubungan dengan sistem budidaya KJA di antaranya peningkatan kandungan nutrien di perairan yang berasal dari sisa pakan, ekskresi, dan feses ikan, serta kemungkinan dampak yang ditimbulkan terhadap kualitas perairan, lingkungan, dan kondisi kesehatan ekosistem (León, 2006 dalam Halwart et al., 2007).

Hasil evaluasi beberapa parameter kualitas air penting Danau Maninjau pada tahun 2009 menunjukkan bahwa perairan tersebut telah mengalami perubahan ke arah yang lebih buruk (tercemar). Standar perhitungan dengan metode Storet (Centre, 1977) kualitas air dibagi dalam empat (4) kelas, di mana kategori kelas I dan II untuk bahan baku air minum, kelas III untuk kegiatan perikanan dan kelas IV air buangan limbah industri. Data hasil perhitungan dengan metode Storet yang didasarkan pada 
Tabel 1. Parameter fisika dan kimia yang sudah melebihi baku mutu peruntukannya

\begin{tabular}{ccccc}
\hline Sampel & Kelas I & Kelas II & Kelas III & Kelas IV \\
\hline \multirow{3}{*}{ Air Danau Maninjau } & COD, total fosfat, Hg, DDT, $\mathrm{H}_{2} \mathrm{~S}$, & Total fosfat, $\mathrm{Hg}$, & $\mathrm{Hg}, \mathrm{DDT}, \mathrm{H}_{2} \mathrm{~S}$ & $\mathrm{Hg}, \mathrm{DDT}, \mathrm{H}_{2} \mathrm{~S}$ \\
& Aldrin, Heptaklor EP, DO & DDT, $\mathrm{H}_{2} \mathrm{~S}$ & -28 (TR) & -28 (TR) \\
\hline
\end{tabular}

Keterangan: TB (tercemar berat), TS (tercemar sedang)

Peraturan Pemerintah No. 82 Tahun 2001 tentang pengelolaan kualitas air dan pengendalian pencemaran air, tingkat pencemaran di Danau Maninjau untuk kategori kelas I dan II sudah tercemar berat dan kategori kelas III dan IV dalam kondisi tercemar ringan. Parameter yang mengakibatkan pencemaran di setiap kelompok disajikan pada Tabel 1.

Peruntukan air untuk kegiatan budidaya ikan air tawar berada pada kategori kelas III. Dari hasil perhitungan, kualitas air Danau Maninjau masih dalam kategori tercemar ringan. Parameter-parameter yang sudah melebihi standar baku mutu untuk budidaya ikan di perairan Danau Maninjau yaitu: DDT, $\mathrm{H}_{2} \mathrm{~S}$, dan air raksa.

Namun demikian, tingkat pencemaran perairan Danau Maninjau sebagian besar sumbernya bukan berasal dari kegiatan budidaya ikan melainkan dari aktivitas lain di luar ekosistem perairan Danau Maninjau. Sehingga aktivitas budidaya ikan di Danau Maninjau masih dapat diteruskan.

\section{KONDISI BUDIDAYA PERIKANAN}

\section{Budidaya Ikan Mas}

Salah satu komoditas yang sudah berkembang di Danau Maninjau adalah ikan mas (Cyprinus carpio). Komoditas ini merupakan komoditas unggulan yang memiliki pangsa pasar yang tinggi dan stabil di Kabupaten Agam. Produksi ikan yang dihasilkan dari KJA di Danau Maninjau mencapai 16.816,8 ton/tahun, hasil ini bukan saja untuk memenuhi kebutuhan konsumen di Kabupaten Agam, juga dijual ke daerah lain seperti Sumatera Barat dan Sumatera Utara. Kegiatan budidaya ikan mas dalam KJA di Danau Maninjau disajikan pada Gambar 3.

Kelangsungan budidaya ikan mas sedikit mengalami kendala yaitu tingkat serangan penyakit cukup tinggi, hal ini disebabkan karena fluktuasi suhu air Danau Maninjau cukup ekstrim. Suhu optimal untuk budidaya ikan mas yaitu berkisar antara $26^{\circ} \mathrm{C}-28^{\circ} \mathrm{C}$ (Cholik et al., 2005), sedangkan pada saat pengukuran suhu air Danau Maninjau berkisar antara $27,86^{\circ} \mathrm{C}-30,02^{\circ} \mathrm{C}$, kondisi ini kurang optimum untuk budidaya ikan mas. Namun demikian,

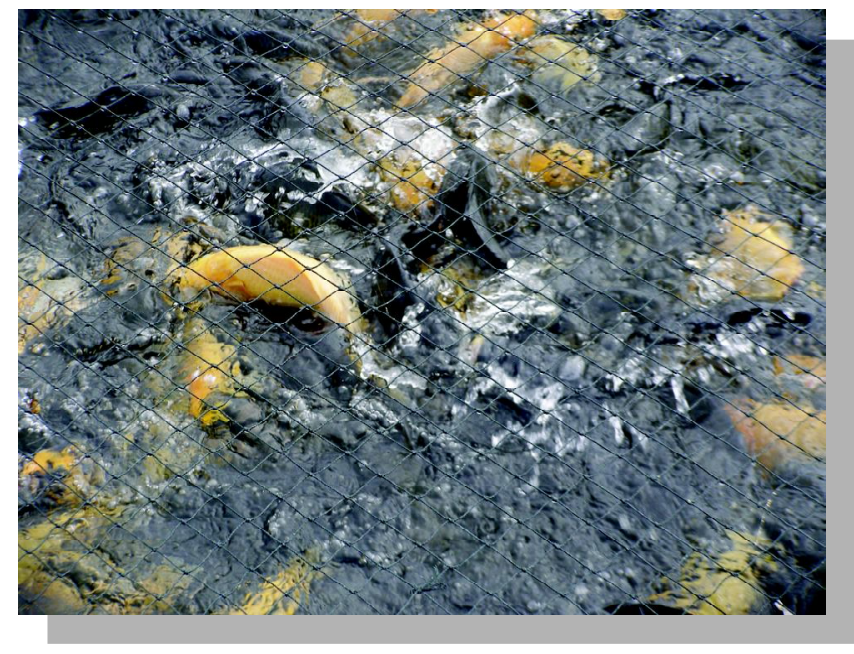

Gambar 3. Kegiatan budidaya ikan mas di KJA Danau Maninjau

karena kondisi perairannya masih termasuk kategori tercemar ringan (Tabel 1), ikan mas masih dapat bertahan.

Kendala lain dalam keberhasilan usaha budidaya ikan mas adalah terbatasnya ketersediaan benih unggul. Sampai saat ini ketersediaan benih 90\%masih mengandalkan dari luar Kabupaten Agam di antaranya dari Medan dan Jambi. Padahal kebutuhan benih ikan mas untuk wilayah Kabupaten Agam mencapai 80.000.000 ekor/tahun (LIPI, 2007). Sehingga biaya produksi menjadi tinggi karena dibebani biaya transportasi untuk pengangkutan benih. Untuk menekan biaya produksi tersebut, harus dilakukan upaya dengan penyediaan benih unggul yang diproduksi dekat dengan lokasi pembesaran (sekitar Danau Maninjau). Karena dengan benih unggul akan menaikan tingkat sintasan dan memperpendek jangka waktu pemeliharaan, sedangkan jarak pembelian benih semakin dekat akan menekan biaya transportasi.

\section{Budidaya Ikan Nila}

Budidaya ikan nila di Danau Maninjau belum berkembang sepesat budidaya ikan mas. Namun demikian, budidaya ikan nila gift akhir-akhir ini grafiknya terus meningkat. Hal ini disebabkan oleh fish bihavior ikan nila yang mempunyai toleransi terhadap perubahan lingkungan 
yang sangat ekstrim. Faktor lain yang mendukung percepatan budidaya ikan nila di Danau Maninjau adalah tingkat infeksi penyakit yang lebih rendah dibandingkan dengan ikan mas.

Budidaya ikan nila di Danau Maninjau telah didukung oleh unit perbenihan rakyat (UPR) yang telah berkembang di Kabupaten Agam, sehingga kebutuhan benih sampai saat ini belum menjadi kendala. Hal lain yang mendukung percepatan budidaya ikan nila adalah tingkat konsumsi ikan nila oleh masyarakat cukup tinggi, terbukti dari restoran-restoran yang ada di Kabupaten Agam hampir selalu menyediakan menu masakan dari ikan nila.

Selain menjadi komoditas utama pada sistem KJA tunggal, juga dimanfaatkan sebagai komoditas yang dibudidayakan pada sistem KJA ganda. Pada umumnya budidaya ikan dengan sistem KJA ganda komoditas utamanya adalah ikan mas yang dipelihara di KJA lapis dalam dan ikan nila dipelihara pada keramba lapis luar. Sehingga efektivitas dan efisiensi pakan dapat ditingkatkan, karena sisa buangan pakan yang merupakan penyumbang terbesar dari kegiatan budidaya ikan terhadap tingkat eutrofikasi dapat diturunkan.

\section{PROSPEK USAHA BUDIDAYA PERIKANAN}

Peluang usaha untuk budidaya ikan di Danau Maninjau masih terbuka lebar. Dari luas Danau Maninjau sekitar 9.737,50 ha yang digunakan untuk budidaya baru sebesar 3,89\% Artinya kalau dilihat dari caraying capacity sekitar $10 \%$ yang bisa digunakan untuk budidaya perikanan, sehingga masih ada sekitar $6,11 \%$ belum dimanfaatkan untuk usaha budidaya ikan serta fasilitas umum lainnya seperti sarana wisata dan fasilitas penunjang lainnya.

Bukan hanya segmen usaha pembesaran ikan di KJA yang dapat dikembangkan di Danau Maninjau, segmen lain yang diusahakan di Kabupaten Agam adalah perbenihan, pakan ikan, transportasi, sarana dan prasarana budidaya, dan usaha pemasaran. Dengan berkembangnya segmentasi usaha pada kegiatan budidaya ikan di Danau Maninjau, akan membuka lapangan pekerjaan bagi masyarakat khususnya di sekitar danau dan Kabupaten Agam pada umumnya.

\section{KESIMPULAN}

Kegiatan budidaya ikan di Danau Maninjau masih sangat prosfektif untuk dikembangkan. Dilihat dari kondisi parameter lingkungannya masih mendukung, dilihat dari daya dukungnya baru 3,89\%yang dimanfaatkan dari total 10\%caraying capacity, sehingga masih ada sekitar 6,11\%belum dimanfaatkan untuk usaha budidaya. Selain usaha budidaya, segmen lain yang bisa dikembangkan di sekitar Danau di antaranya perbenihan, pakan ikan, transportasi, sarana dan prasarana budidaya.

\section{DAFTAR ACUAN}

Centre, L.W. 1977. Environmental Impact Assesment. MC GraweHill Company. University of Oklahoma USA.

Cholik, F., Jagatraya, A.G., Poernomo, R.P., \& Jauzi, A. 2005. Akuakultur Tumpuan Harapan Masa Depan Bangsa. Masyarakat Perikanan Nusantara kerjasama dengan Taman Akuarium Air Tawar. Jakarta, $415 \mathrm{hlm}$.

Halwart, M., Soto, D., \& Arthur, J.R. 2007. Cage Aquaculture-Regional reviews and global overview. (Eds.) FAO Fisheries Technical Paper, Rome, 498: 241 pp.

Jusuf, R., Widipaminto, A., Irianti, G., \& Hidayat, N. 2004. Pembuatan Informasi Penutupan Lahan Spasial Kabupaten Agam, Sumatera Barat. Berita Indraja, Pusdata dan Puslittnak., III(5): 11-15.

Lembaga IImu Pengetahuan Indonesia (LIPI). 2007. Program Penyehatan Danau Maninjau dan Pemberdayaan Masyarakat di Sekitar Danau. Pusat Penelitian Limnologi-LIPI, $38 \mathrm{hIm}$. 